\title{
Pancreatic alpha cell mass in European subjects with type 2 diabetes
}

\author{
J. C. Henquin • J. Rahier
}

Received: 3 January 2011 / Accepted: 18 February 2011 /Published online: 5 April 2011

(C) The Author(s) 2011. This article is published with open access at Springerlink.com

\begin{abstract}
Aims/hypothesis Type 2 diabetes is a bi-hormonal disease characterised by relative hypoinsulinaemia and hyperglucagonaemia with elevated blood glucose levels. Besides pancreatic beta cell defects, a low number of beta cells (low beta cell mass) may contribute to the insufficient secretion of insulin. In this study our aim was to determine whether the alpha cell mass is also altered.

Methods Using a point counting method, we measured the ratio of alpha to beta cell areas in pancreas samples obtained at autopsy from 50 type 2 diabetic subjects, whose beta cell mass had previously been found to be $36 \%$ lower than that of 52 non-diabetic subjects.

Results The topography of alpha and beta cells was similar in both groups: many alpha cells were localised in the centre of the islets and the ratio of alpha/beta cell areas increased with islet size. The average ratio was significantly higher in type 2 diabetic subjects $(0.72)$ than in nondiabetic subjects $(0.42)$, with, however, a large overlap between the two groups. In contrast, the alpha cell mass was virtually identical in type 2 diabetic subjects $(366 \mathrm{mg}$ )
\end{abstract}

Electronic supplementary material The online version of this article (doi:10.1007/s00125-011-2118-4) contains supplementary material, which is available to authorised users.

J. C. Henquin · J. Rahier

Department of Pathology, Faculty of Medicine,

University of Louvain,

Brussels, Belgium

J. C. Henquin $(\bowtie)$

Unit of Endocrinology and Metabolism, Faculty of Medicine,

University of Louvain,

UCL 55.30, Avenue Hippocrate 55,

1200 Brussels, Belgium

e-mail: jean-claude.henquin@uclouvain.be and non-diabetic subjects (342 mg), and was not influenced by sex, BMI or type of diabetes treatment.

Conclusions The higher proportion of alpha to beta cells in the islets of some type 2 diabetic subjects is due to a decrease in beta cell number rather than an increase in alpha cell number. This imbalance may contribute to alterations in the normal inhibitory influence exerted by beta cells on alpha cells, and lead to the relative hyperglucagonaemia observed in type 2 diabetes.

Keywords Alpha cell mass · Beta cell mass · Diabetes pathogenesis · Endocrine pancreas · Glucagon · Insulin secretion · Islet cells · Pancreatic islets · Type 2 diabetes

\section{Introduction}

Hyperglycaemia in type 2 diabetes results from insufficient and inappropriately sluggish insulin secretion in a context of diminished insulin action in target tissues $[1,2]$. These secretory defects often coexist with a relatively low beta cell number, commonly referred to as a decrease in beta cell mass. On average, this decrease amounted to $30-50 \%$ of normal in postmortem morphological comparisons of pancreatic samples from non-diabetic and type 2 diabetic subjects [3-7]. Converging observations also indicate that the disease is bi-hormonal and entails abnormalities of glucagon secretion by alpha cells. Type 2 diabetic patients show excessive plasma glucagon levels for their glycaemia. This relative hyperglucagonaemia aggravates the consequences of their relative hypoinsulinaemia by activating glucose production in the liver [8-10].

Inhibition of glucagon secretion by glucose encompasses direct effects on alpha cells and indirect actions via signals produced by neighbouring islet cells [11]. Although 
intrinsic abnormalities in alpha cells are possible in type 2 diabetes, dysregulation of glucagon secretion is often attributed to perturbations in paracrine interactions between beta and alpha cells [10]. Changes in alpha cell mass could also underlie such perturbations. Old postmortem studies using histochemical methods to distinguish beta and alpha cells have reported that alpha cell mass was unchanged [12] or decreased by about $35 \%[13,14]$ in maturity onsetdiabetes (type 2 diabetes) when compared with non-diabetic controls. More recent studies using immunohistochemical identification of the two cell types have reported that the relative volume density of alpha cells vs beta cells tended to be higher $[15,16]$ or was significantly higher $[3,4,6,17-$ $19]$ in type 2 diabetic patients than in non-diabetic subjects. In some of these studies, alpha cell mass could be calculated and was reported to be decreased by about $45 \%$ [16], unchanged [15] or increased by $40-80 \%[4,17]$. In all of these series, the small number of subjects (2-15 per group) and the high inter-subject variability unfortunately undermine the reliability of certain conclusions. We have therefore measured alpha cell mass in a larger series of non-diabetic and type 2 diabetic subjects whose beta cell mass was reported recently [7].

\section{Methods}

Subjects The study, conducted according to the regulations of the local ethics committee, was performed on pancreatic samples obtained at autopsy (within $12 \mathrm{~h}$ of death) of the subjects in whom we previously measured beta cell mass [7]. All the 52 non-diabetic subjects could be studied again, but adequate samples were available from only 50 of the 57 type 2 diabetic subjects. Omission of these seven type 2 diabetic subjects had no significant impact on the conclusions of our previous study. For instance, beta cell mass averaged $567 \pm 248 \mathrm{mg}$ in these 50 type 2 diabetic subjects as compared with $573 \pm 259 \mathrm{mg}$ in the whole group of 57 subjects [7]. Clinical characteristics of the studied subjects are given in electronic supplementary material (ESM) Tables 1 and 2.

Pancreas processing, microscopic examination and analysis of results Pancreatic sections immunostained for insulin and glucagon were analysed at a final magnification of $\times 400$. The ratio of alpha/beta cell areas was determined by point counting, using a 100 point lattice [20]. In practice, the number of points corresponding to alpha cells and beta cells were counted for each islet in all fields. Small structures of a few cells were included in the analysis, but single cells were not counted. The total number of points (alpha + beta cells) counted in this way averaged 1,794 (696-4,064) in non-diabetic subjects and 1,451 (698-
3,266 ) in type 2 diabetic subjects. From the measured ratio of alpha/beta cell areas and the known beta cell mass [7], the alpha cell mass was calculated (see ESM for further details on methods).

Presentation of results Most figures show scatter plots of individual values. As all sets of data passed the KolmogorovSmirnov test of normality, values for non-diabetic and type 2 diabetic groups are presented as means $\pm \mathrm{SD}$, and the differences were assessed by Student's $t$ test. Comparisons using a non-parametric Mann-Whitney test yielded similar levels of significance.

\section{Results}

Morphological aspects of the islets Variability in the cellular composition of islets was evident in the pancreas of non-diabetic subjects (ESM Fig. 1a-c). Alpha cells sometimes formed a discontinuous peripheral rim around the core of beta cells, but were more often localised in the centre of the islets, usually close to vessels. In some nondiabetic subjects, large islets with a vast majority of alpha cells were occasionally observed (ESM Fig. 1c). The interislet variability in the proportions and the topography of alpha and beta cells was not strikingly altered in the pancreas of type 2 diabetic subjects (ESM Fig. 1d, e). However, islets virtually devoid of beta cells (ESM Fig. 1f) were observed more often than in non-diabetic subjects (see quantification below).

Ratio of alpha cell to beta cell areas Because the beta cell volume density is higher in the tail than the body of the pancreas [7], we first compared specimens from the two regions. The ratio of alpha/beta cell areas was higher in the tail of the pancreas in 18/30 non-diabetic subjects, but mean values were similar $(0.437 \pm 0.146$ vs $0.395 \pm$ 0.148 ; NS by paired $t$ test). In type 2 diabetic subjects, the ratio of alpha/beta cell areas was higher in the tail of the pancreas in 14/30 subjects, and mean values were not significantly different. Therefore, individual ratios of alpha/beta cell areas presented in Fig. 1 are averages of measurements in the body and tail of the pancreas, when available, or results of measurements in the body of the pancreas only.

The ratio of alpha/beta cell areas was variable $(\sim 3 \times)$ between non-diabetic subjects (Fig. 1a). Among type 2 diabetic subjects, one individual showed an extremely high ratio (3.2) because of a very low (the lowest) number of beta cells. This extreme value was omitted from further analyses based on the ratio, except when specified. Even without this outlier, the ratio of alpha/beta cell areas was more variable $(\sim 4.6 \times)$ among type 2 diabetic than non- 
a

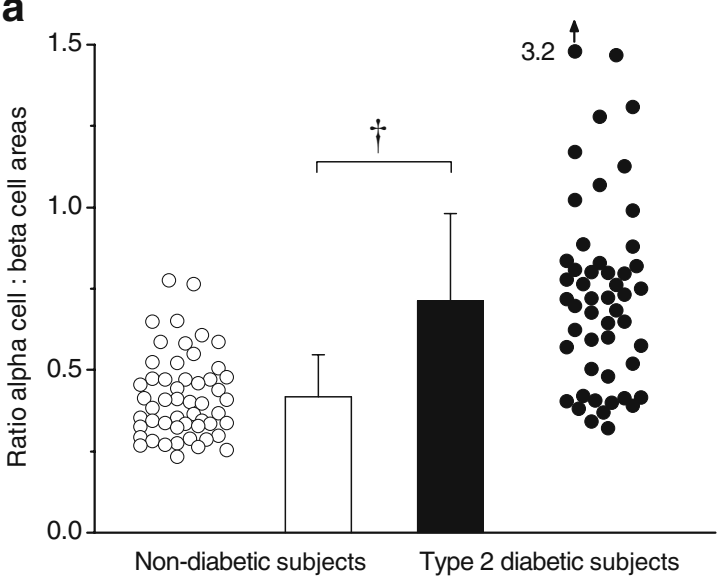

b

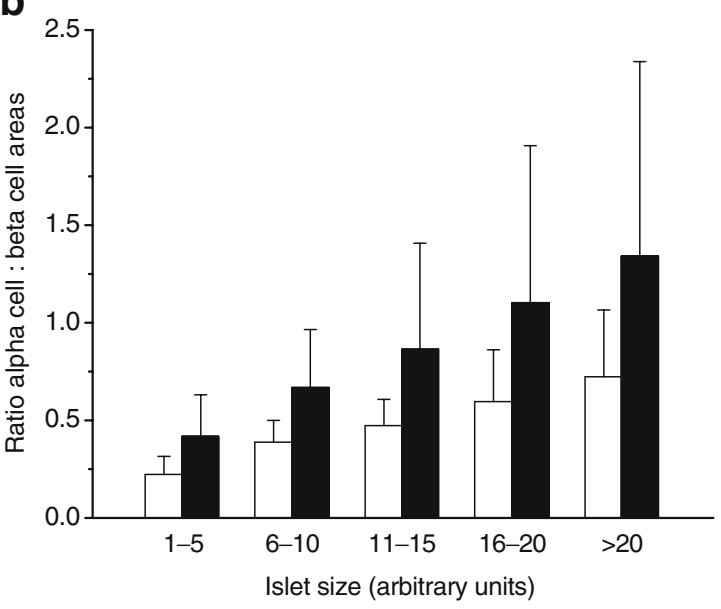

Fig. 1 Ratio of alpha cell/beta cell areas in 52 non-diabetic subjects (ND) and 50 type 2 diabetic (T2D) subjects. a Scatter plots of ratios and means $\pm \mathrm{SD}:{ }^{\dagger} p<0.0001$. b Mean ratios $\pm \mathrm{SD}$ in islet profiles of increasing sizes. Five classes were defined according to the total number of points (alpha + beta) counted in each profile: $1-5,6-10$, $11-15,16-20$ and $>20$. The smallest category corresponds to an area between 625 and $3,125 \mu^{2}(6-27$ cells $)$ and the largest one to $>12,500 \mu^{2}$ (>110 cells). However, these are minimum numbers because the examined islet profiles also contained structures (vessels,

diabetic subjects. On average, it was $1.7 \times$ higher in type 2 diabetic than non-diabetic subjects $(0.72 \pm 0.27$ vs $0.42 \pm$ $0.13 ; p<0.0001)$. Note, however, the large overlap between the two groups (Fig. 1a). The ratio was within the range of non-diabetic values in 32/50 type 2 diabetic subjects.

In subsets of 24 subjects, we assessed whether the ratio of alpha/beta cell areas varied with islet size. Figure $1 \mathrm{~b}$ shows that the ratio increased with the size of the islet profile in non-diabetic subjects: from $0.22 \pm 0.09$ in the smallest profiles to $0.72 \pm 0.34$ in the largest ones $(p<0.001)$. A similar distribution of alpha cells was observed in islets from type 2 diabetic subjects, so that the difference between the two groups $(\sim 1.7 \times)$ persisted
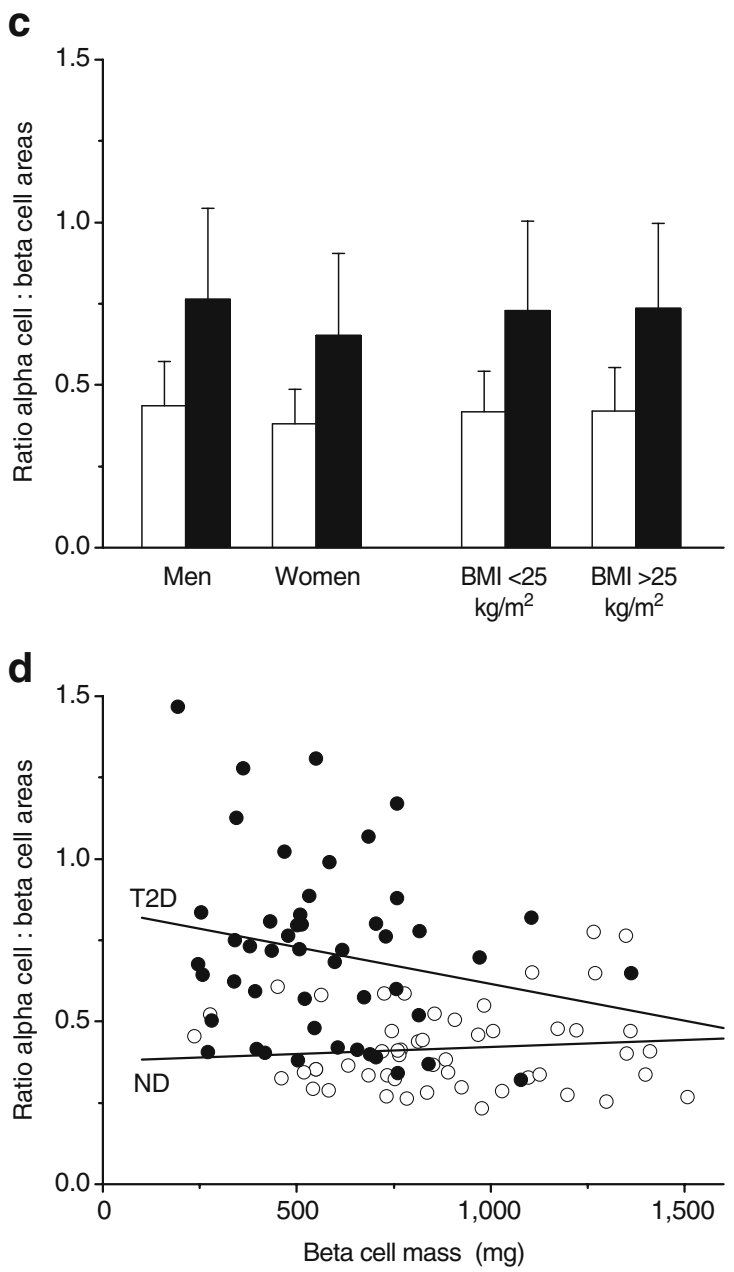

non-stained cells) that were not counted; white bars, ND; black bars, T2D. c Mean ratios $\pm \mathrm{SD}$ in ND and T2D men $(n=35$ and 26, respectively) and ND and T2D women ( $n=17$ and 23 , respectively) and in ND and T2D subjects with a BMI below $25 \mathrm{~kg} / \mathrm{m}^{2}(n=26$ and 13 , respectively) or above $25 \mathrm{~kg} / \mathrm{m}^{2}$ ( $n=26$ and 36 , respectively): white bars, ND; black bars, T2D. d Ratio of alpha/beta cell areas as a function of beta cell mass in ND subjects (white circles; $y=0.38+$ $0.43 \times 10^{-4} x$ ) and T2D subjects (black circles; $y=0.84-0.23 \times 10^{-3} x$ )

irrespective of the size of the islet profile (Fig. 1b). In the same subsets of 24 subjects, we also quantified the visual impression that islets with a large majority of alpha cells were more frequent in the pancreas from type 2 diabetic than non-diabetic subjects. The ratio of alpha/beta cell areas was $\geq 3$ in $6.8 \pm 5.7 \%$ of islet profiles in type 2 diabetic subjects, as compared with $2.7 \pm 2.1 \%$ in nondiabetic subjects $(p<0.005)$.

In the whole groups of 52 non-diabetic and 50 type 2 diabetic subjects, there was no difference in mean ratios of alpha/beta cell areas between men and women or between subjects with a BMI lower or higher than $25 \mathrm{~kg} / \mathrm{m}^{2}$ (Fig. 1c), but the difference in ratio between non-diabetic and type 2 diabetic subjects remained highly significant $(p<0.001)$ in 
each category. No correlation was found between the ratio of alpha/beta cell areas and BMI or age in either non-diabetic or type 2 diabetic subjects (Table 1). As shown in Fig. 1d (open symbols), the ratio of alpha/beta cell areas was completely independent of the beta cell mass in nondiabetic subjects $(r=0.100, p=0.48)$. There was no significant correlation either in type 2 diabetic subjects (Fig. 1d, filled symbols; $r=-0.204, p=0.16$ ). However, the highest ratios were often measured in individuals with a relatively low beta cell mass. Moreover, the negative correlation became significant $(r=-0.333, p=0.02)$ when the individual with a very high ratio of alpha/beta cell areas (3.2 for a beta cell mass of $105 \mathrm{mg}$ ) was included in the analysis.

Alpha cell mass From the ratio of alpha/beta cell areas measured in this study and the beta cell mass previously measured in the same subjects [7], we calculated the alpha cell mass. As shown in Fig. 2a, inter-subject variability was marked and similar in both groups $(\sim 9 \times)$, with almost identical mean values $(347 \pm 183 \mathrm{mg}$ in non-diabetic subjects and $366 \pm 186 \mathrm{mg}$ in type 2 diabetic subjects). This contrasts with the $36 \%$ difference in beta cell mass in the same subjects (Fig. 2b) [7]. The alpha cell mass was not significantly different between men and women. It slightly decreased with age in non-diabetic subjects but not in type 2 diabetic subjects, and was not correlated with BMI in either group (Table 1$)$. There was a strong $(p<0.0001)$ correlation between the alpha cell mass and the beta cell mass in both groups ( $r=0.725$ in non-diabetic subjects and $r=0.664$ in type 2 diabetic subjects) (Fig. 2c).

Figure $2 \mathrm{~d}$ compares the relative alpha cell and beta cell masses in the different groups. The mass ratio was virtually identical (0.39) in lean and overweight nondiabetic subjects. It was similarly augmented (between 0.6 and 0.7 ) in lean and overweight/obese type 2 diabetic subjects, regardless of their treatment by oral drug or insulin.

\section{Discussion}

We report that the average pancreatic alpha cell mass is similar in a series of 52 non-diabetic subjects and 50 type 2 diabetic subjects. However, owing to the $\sim 36 \%$ decrease in beta cell mass in these type 2 diabetic subjects, their alpha cell/beta cell mass ratio is increased $\sim 1.7 \times$ compared with non-diabetic subjects.

The proportion of alpha and beta cells in human islets has previously been determined, usually in small numbers of islets from limited numbers of non-diabetic subjects. When identified nucleated cells were counted in isolated islets or in islets in situ, the ratio of alpha/beta cell numbers ranged from 0.37 to 0.55 [18, 21-23]. When alpha/beta cell areas were measured by semi-automatic imaging programmes, the ratio ranged from 0.24 in isolated islets [24] to 0.56 in islets in situ [19]. Using a point counting method to examine islets in situ, we measured an average ratio of alpha/beta cell areas of 0.42 in 52 non-diabetic subjects. This value is in the upper range of previous measurements by point counting $(0.28-0.44)$ in smaller series $[4,6,16$, 17]. It is important to underline that measurements of relative cell area do not adequately reflect relative cell numbers because alpha cells are smaller than beta cells [25]. Our measurements therefore underestimate the ratio of alpha/beta cell numbers but, unlike the latter, permit the correct calculation of alpha cell mass.

Recent studies focusing on the topography of the different cell types in islets have emphasised that, in contrast to rodent islets, the majority of alpha cells do not form a peripheral rim in normal human islets, but are concentrated in the centre [21-24] in close proximity to vessels [19]. Our observations agree with these descriptions. Moreover, our analysis of 100-300 islet profiles in each of 30 pancreas samples shows that the ratio of alpha/ beta cell areas increases with apparent size of the islet, providing further quantitative support to previous conclusions [19] that alpha cells are preferentially localised in the
Table 1 Correlation between the ratio of alpha/beta cell areas, alpha cell mass or beta cell mass, and age or BMI, in non-diabetic and type 2 diabetic subjects

${ }^{a}$ Values for beta cell mass are taken from Rahier et al. [7]

\begin{tabular}{|c|c|c|c|c|}
\hline \multirow[t]{2}{*}{ Variable } & \multicolumn{2}{|c|}{ Non-diabetic subjects $(n=52)$} & \multicolumn{2}{|c|}{ Type 2 diabetic subjects $(n=50)$} \\
\hline & $r$ & $p$ value & $r$ & $p$ value \\
\hline \multicolumn{5}{|c|}{ Ratio alpha/beta cell areas vs } \\
\hline Age & -0.234 & 0.096 & 0.068 & 0.644 \\
\hline BMI & 0.026 & 0.858 & -0.145 & 0.319 \\
\hline \multicolumn{5}{|c|}{ Alpha cell mass vs } \\
\hline Age & -0.361 & 0.009 & -0.150 & 0.300 \\
\hline BMI & 0.224 & 0.111 & -0.079 & 0.584 \\
\hline \multicolumn{5}{|c|}{ Beta cell mass ${ }^{\mathrm{a}}$ vs } \\
\hline Age & -0.278 & 0.046 & -0.218 & 0.128 \\
\hline BMI & 0.341 & 0.013 & 0.311 & 0.028 \\
\hline
\end{tabular}






b

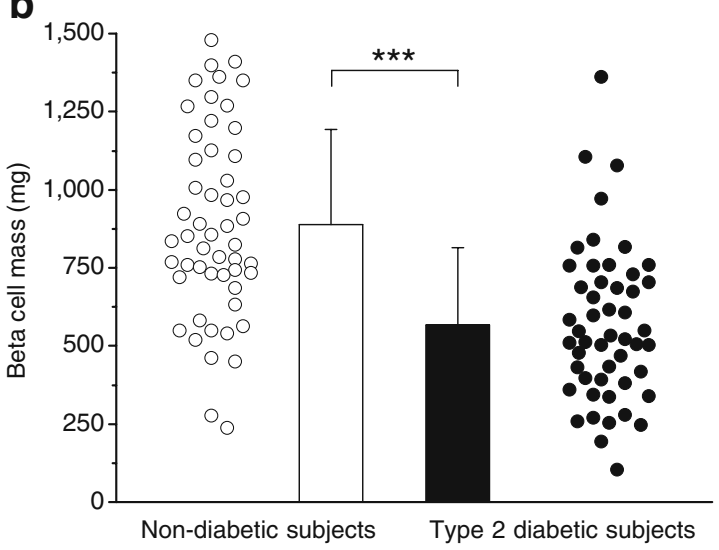

Fig. 2 a Alpha cell mass in the pancreas of 52 non-diabetic (ND) subjects and 50 type 2 diabetic (T2D) subjects. Scatter plot and means \pm $\mathrm{SD}$. b Beta cell mass in the pancreas of the same subjects; data taken from Rahier et al. [7] with slight modifications; $* * * p<0.001$. c Correlations between alpha cell mass and beta cell mass in ND

centre of large islets and in the mantle region of small islets. The reason why the proportion of alpha cells increases with the size of the islet $[6,19]$ is not known, but this variation may complicate comparisons of data obtained in different studies if not all sections of islets are counted. Most importantly, we have also established that this relative distribution of alpha and beta cells is not perturbed in islets from type 2 diabetic subjects: the proportion of alpha cells also increases with the size of the islet profile, so that the difference between diabetic samples and controls is not restricted to one particular islet category.

Beta cell mass slightly increases with BMI in nondiabetic subjects [5-7]. This increase is usually viewed as an adaptation to greater insulin needs to overcome the resistance of peripheral tissues. It was therefore unexpected that the ratio of alpha/beta cell areas did not decrease with the increase in BMI. We have no explanation, but wish to
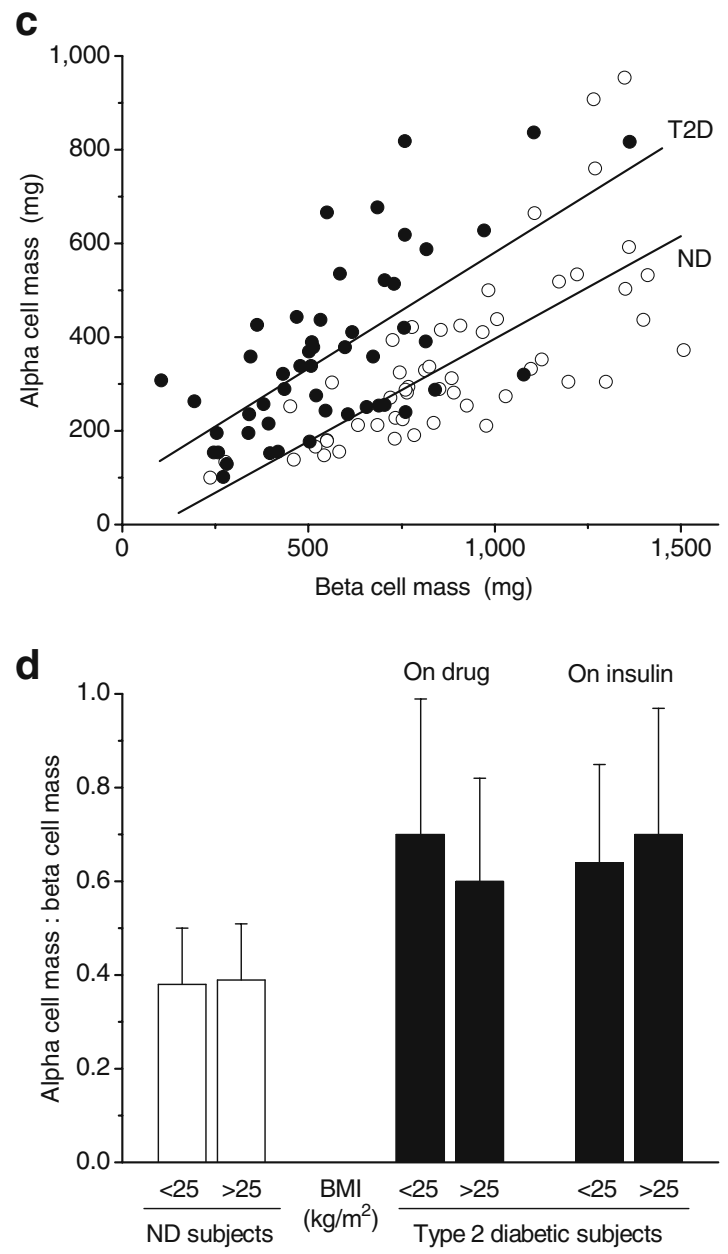

subjects (white circles; $y=-42+0.44 x$ ) and T2D subjects (black circles; $y=86+0.49 x$ ). d Ratio of alpha cell mass to beta cell mass in ND subjects with a BMI $<25(n=26)$ and $>25(n=26) \mathrm{kg} / \mathrm{m}^{2}$, and in T2D subjects subdivided according to treatment (drug or insulin) and BMI $(n=8,16,5,20$ from left to right)

point out that beta cell mass was only $20 \%$ higher ( 972 vs $804 \mathrm{mg}$ ) in our group of overweight non-diabetic subjects (mean BMI $30 \mathrm{~kg} / \mathrm{m}^{2}$, no individual $>40 \mathrm{~kg} / \mathrm{m}^{2}$ ) than in our group of lean non-diabetic subjects (mean BMI $22 \mathrm{~kg} / \mathrm{m}^{2}$ ) [7]. It is also notable that ageing was accompanied by a small decrease of both alpha and beta cell mass in nondiabetic subjects.

From our measurements, we can conclude that the relative hyperglucagonaemia of type 2 diabetic subjects is not the consequence of an increased alpha cell mass. The elevated ratio of alpha/beta cell areas measured in the pancreas of these subjects is attributable to the decrease in beta cell number [7]. If alpha cell function is controlled by direct contact between the two cell types or by products released by beta cells (insulin or others), and reaching alpha cells via either a paracrine route or the islet microvasculature, perturbations of glucagon secretion may obviously result from the lower 
relative number of beta vs alpha cells. This may be particularly true in the generally large islets quasiexclusively composed of alpha cells. However, qualitative and quantitative relationships between both cell types are not consistently perturbed in all islets from all type 2 diabetic subjects. Some type 2 diabetic individuals have beta and alpha cell masses similar to those of non-diabetic individuals. One insurmountable limitation in the interpretation of our results, obtained from autopsy specimens, is the impossibility of correlating the extent of dysregulation of glucagon secretion with changes in the cellular composition of islets. In the absence of changes in islet cell numbers, relative hyperglucagonaemia might be secondary to functional perturbations of beta cells [10] or intrinsic defects of alpha cells.

Acknowledgements We thank S. Godecharles for technical assistance, S. Lagasse and M. Nenquin for help in the preparation of figures, and Y. Guiot for advice on technical issues. This work was supported by grant ARC 05/10-328 from the Direction de la Recherche Scientifique de la Communauté Française de Belgique and grants 3.4615.05 and 3.4530.08 from the Fonds National de la Recherche Scientifique et Médicale, Bruxelles.

Duality of interest The authors declare that there is no duality of interest associated with this manuscript.

Open Access This article is distributed under the terms of the Creative Commons Attribution Noncommercial License which permits any noncommercial use, distribution, and reproduction in any medium, provided the original author(s) and source are credited.

\section{References}

1. Cerasi E (1995) Insulin deficiency and insulin resistance in the pathogenesis of NIDDM: is divorce possible? Diabetologia 38:992-997

2. Kahn SE, Zraika S, Utzschneider KM, Hull RL (2009) The beta cell lesion in type 2 diabetes: there has to be a primary functional abnormality. Diabetologia 52:1003-1012

3. Clark A, Wells CA, Buley ID et al (1998) Islet amyloid, increased A-cells, reduced B cells and exocrine fibrosis: quantitative changes in pancreas in type 2 diabetes. Diabetes Res 9:151-159

4. Sakuraba H, Mizukami H, Yagihashi N, Wada R, Hanyu C, Yagihashi S (2002) Reduced beta-cell mass and expression of oxidative stress-related DNA damage in the islet of Japanese type II diabetic patients. Diabetologia 45:85-96

5. Butler AE, Janson J, Bonner-Weir S, Ritzel R, Rizza RA, Butler PC (2003) $\beta$-Cell deficit and increased $\beta$-cell apoptosis in humans with type 2 diabetes. Diabetes 52:102-110
6. Yoon KH, Ko SH, Cho JH et al (2003) Selective $\beta$-cell loss and $\alpha$-cell expansion in patients with type 2 diabetes mellitus in Korea. J Clin Endocrinol Metab 88:2300-2308

7. Rahier J, Guiot Y, Goebbels RM, Sempoux C, Henquin JC (2008) Pancreatic $\beta$-cell mass in European subjects with type 2 diabetes. Diabetes Obes Metab 10(Suppl 4):32-42

8. Unger RH, Orci L (1975) The essential role of glucagon in the pathogenesis of diabetes mellitus. Lancet 1:14-16

9. Dunning BE, Gerich JE (2007) The role of $\alpha$-cell dysregulation in fasting and postprandial hyperglycemia in type 2 diabetes and therapeutic implications. Endocr Rev 28:253-283

10. Unger RH, Orci L (2010) Paracrinology of islets and the paracrinopathy of diabetes. Proc Natl Acad Sci USA 107:16009-16012

11. Quesada I, Tudurí E, Ripoll C, Nadal A (2008) Physiology of the pancreatic $\alpha$-cell and glucagon secretion: role in glucose homeostasis and diabetes. J Endocrinol 199:5-19

12. Gepts W (1958) Die histopathologischen Veränderungen der Langerhansschen Inseln und ihre Bedeutung in der Frage der Pathogenese des menschlichen Diabetes [Histopathological changes in the islets of Langerhans and their importance for the pathogenesis of human diabetes]. Endokrinologie 36:185-211 (article in German)

13. Maclean N, Ogilvie RF (1955) Quantitative estimation of the pancreatic islet tissue in diabetic subjects. Diabetes 4:367-376

14. Saito K, Yaginuma N, Takahashi T (1979) Differential volumetry of $\mathrm{A}, \mathrm{B}$ and $\mathrm{D}$ cells in the pancreatic islets of diabetic and nondiabetic subjects. Tohoku J Exp Med 129:273-283

15. Stefan Y, Orci L, Malaisse-Lagae F, Perrelet A, Patel Y, Unger RH (1982) Quantitation of endocrine cell content in the pancreas of nondiabetic and diabetic humans. Diabetes 31:694-700

16. Klöppel G, Lohr M, Habich K, Oberholzer M, Heitz PU (1985) Islet pathology and the pathogenesis of type 1 and type 2 diabetes revisited. Surv Synth Pathol Res 4:110-125

17. Rahier J, Goebbels RM, Henquin JC (1983) Cellular composition of the human diabetic pancreas. Diabetologia 24:366-371

18. Iki K, Pour PM (2007) Distribution of pancreatic endocrine cells including IAPP-expressing cells in non-diabetic and type 2 diabetic cases. J Histochem Cytochem 55:111-118

19. Bosco D, Armanet M, Morel P et al (2010) Unique arrangement of $\alpha$ and $\beta$-cells in human islets of Langerhans. Diabetes 59:1202-1210

20. Chalkley HW (1943) Method for the quantitative morphologic analysis of tissues. J Natl Cancer Inst 4:47-53

21. Deng S, Vatamaniuk M, Huang X et al (2004) Structural and functional abnormalities in the islets isolated from type 2 diabetic subjects. Diabetes 53:624-632

22. Brissova M, Fowler MJ, Nicholson WE et al (2005) Assessment of human pancreatic islet architecture and composition by laser scanning confocal microscopy. J Histochem Cytochem 53:1087-1097

23. Cabrera O, Berman DM, Kenyon NS et al (2006) The unique cytoarchitecture of human pancreatic islets has implications for islet cell function. Proc Natl Acad Sci USA 103:2334-2339

24. Kharouta M, Miller K, Kim A et al (2009) No mantle formation in rodent islets - the prototype of islet revisited. Diabetes Res Clin Pract 85:252-257

25. Heimberg H, De Vos A, Pipeleers D, Thorens B, Schuit F (1995) Differences in glucose transporter gene expression between rat pancreatic alpha- and beta-cells are correlated to differences in glucose transport but not in glucose utilization. J Biol Chem 270:8971-8975 